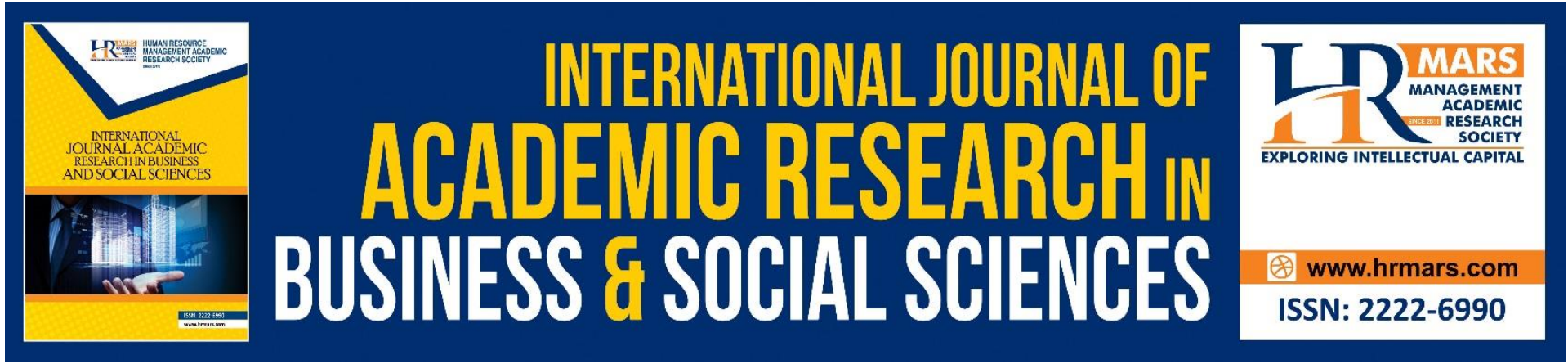

\title{
Exploring and Developing Item Measuring Leadership Practices Inventory (LPI): An Exploratory Factor Analysis Procedure
}

Kang Kooi Wei, Mohd Asri bin Mohd Noor, Mahaliza binti Mansor, Zainudin Awang

To Link this Article: http://dx.doi.org/10.6007/IJARBSS/v11-i7/10157

DOI:10.6007/IJARBSS/v11-i7/10157

Received: 20 May 2021, Revised: 22 June 2021, Accepted: 08 June 2021

Published Online: 24 July 2021

In-Text Citation: (Wei et al., 2021)

To Cite this Article: Wei, K. K., Noor, M. A. bin M., Mansor, M. binti \& Awang, Z. (2021). Exploring and Developing Item Measuring Leadership Practices Inventory (LPI): An Exploratory Factor Analysis Procedure. International Journal of Academic Research in Business and Social Sciences, 11(7), 1332-1343.

Copyright: @ 2021 The Author(s)

Published by Human Resource Management Academic Research Society (www.hrmars.com) This article is published under the Creative Commons Attribution (CC BY 4.0) license. Anyone may reproduce, distribute, translate and create derivative works of this article (for both commercial and non-commercial purposes), subject to full attribution to the original publication and authors. The full terms of this license may be seen at: http://creativecommons.org/licences/by/4.0/legalcode

Vol. 11, No. 7, 2021, Pg. 1332 - 1343

Full Terms \& Conditions of access and use can be found at http://hrmars.com/index.php/pages/detail/publication-ethics 


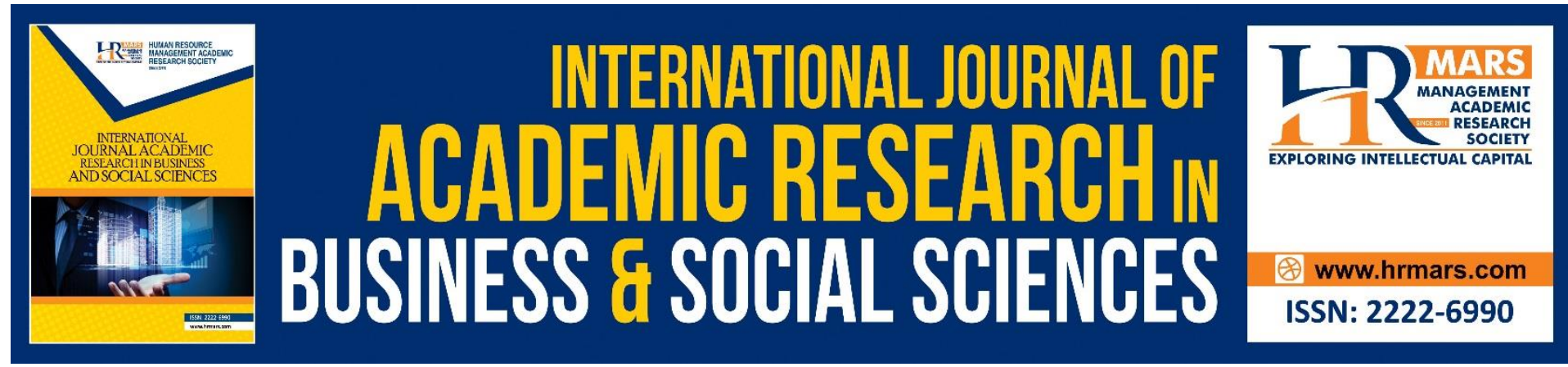

\title{
Exploring and Developing Item Measuring Leadership Practices Inventory (LPI): An Exploratory Factor Analysis Procedure
}

\author{
${ }^{1}$ Kang Kooi Wei, ${ }^{2}$ Mohd Asri bin Mohd Noor, ${ }^{3}$ Mahaliza binti \\ Mansor, ${ }^{4}$ Zainudin Awang \\ 1,2,3 Universiti Pendidikan Sultan Idris, Tg. Malim, Perak. Malaysia; ${ }^{4}$ Universiti Sultan Zainal \\ Abidin, Kuala Terengganu, Terengganu. Malaysia
}

\begin{abstract}
This study aims to develop and validate the instrument measuring Leadership Practices Inventory (LPI) through Exploratory Factor Analysis (EFA). This study employed a crosssectional research design. Study data was obtained from 100 randomly selected lecturers from Kedah Matriculation College using a self-administered questionnaire. The Exploratory Factor Analysis (EFA) procedure has explored the usefulness of measuring items and determined the dimensionality of the construct. Initially there are 30 items measuring the leadership practices construct in Leadership Practices Inventory (LPI). However, after the EFA procedure, the study found that 3 items with factor loading below the cut-off point of .60 were deleted and 27 items with a factor loading above the cut-off point of .6 were retained. The EFA procedure found 5 components that emerged from the items. The results of this study highlighted the importance of leadership practice among the lecturers in Matriculation College. This study validates the components that lead to improve the leadership practices among lecturers. This study adds a contribution to the measurement of the Leadership Practices Inventory (LPI), mainly in the Malaysia Matriculation College context.
\end{abstract}

Keywords: Leadership Practices, Matriculation College, Exploratory Factor Analysis, Lecturer, Leadership Practices Inventory (LPI).

\section{Introduction}

Lecturers play an important role in the development of the country. The transformation of the education system towards the fourth industrial revolution requires effective teacher leaders as well as teacher leadership to achieve national aspirations. Lecturers as educators in colleges are also leaders, advisors and agents of change in society. Teachers are not just teaching in the classroom, teachers need to be prepared to educated and guide students (Mahat, 2009). The role of these teachers can help the country produce a comprehensive and competitive young human capital with balanced and holistic characteristics can be born with the existence of teacher leaders who can lead students. Therefore, teachers who teach in the classroom are also leaders and teachers (Hamidah et al., 2017). Teachers as leaders play an important role in the development of the country. 
In the list of duties of Education Service Officer (PPP) in the Matriculation College of the Ministry of Education Malaysia (MOE), the duties of a lecturer (academic) include unit management and leadership, teaching and learning, examination and assessment, subject unit management, student management, field special duties as well as general duties as directed by the director, head of department and head of unit from time to time. This PPP task list has shown that matriculation lecturers are leaders in the class as well as in their respective field units. Therefore, a study to examine leadership practices among matriculation lecturers is suitable to be implemented to ensure the development and advancement of matriculation colleges.

\section{Literature Review}

A leader is a person who has the power and authority to lead an organization. The leadership style of a leader is known as the type of leadership practiced by the leader (Faizal et al., 2014). Therefore, every organization has leaders who practice their own leadership style.

Leadership in an organization consists of instructional leadership, management leadership, transformational leadership, moral leadership, teacher leadership, systems leadership and contingent leadership (Bush \& Glover, 2014). According to Gunter (2005), the field of leadership in schools has undergone a transformation from educational administration transformed to educational management and more recently to educational leadership.

A study conducted by Lipham (1981) was able to distinguish the concept of leadership from administration. Administration is an activity that involves structures and procedures to achieve the goals of an organization. To achieve that goal, individuals in the administration need to have permanent power and authority. While leaders are people who are sensitive to change inside and outside the organizational environment. Leadership is the beginning of a positive culture in an organization. In summary, an administrator is considered a leader when he or she makes changes in his or her organization.

In terms of leadership and management, Bennis (1989); Mitchell and Tucker (1992) stated that management is the process of handling a task on a routine basis without taking into account the need to perform the task. On the other hand, leadership is the process of handling the right tasks and making changes according to current needs. The concept of leadership is the process of influencing members in an organization. Moreover, the concept of leadership is broader compared to the concept of administration and management (Faizal et al., 2014). Educators in this study referring to matriculation lecturers are also individuals who able to lead the change in the organization. Thus, lecturers also have leadership characteristics that are practiced in their daily tasks.

There are three dimensions in leadership, namely leadership with influence, leadership with values and leadership with vision. Yulk (2002) defines leadership as reflecting a process of social influence in which the influence of intention is given by one person or one group over another person or group to organize activities and relationship in a group or organization. Leadership is increasingly associated with values. According to Day, Harris and Hadfield's (2000), a good leader can be identified by his or her personal traits that are able to convey a set of values and education that can clearly indicate their moral purpose towards the school. Vision has played an important role in effective leadership. The articulation of a clear vision has the potential to develop schools but empirical evidence on its effectiveness is still mixed (Bush and Glover, 2014). 


\section{Leadership Practices Inventory (LPI)}

Kouzes and Posner (2012) have set characteristics to identify successful leadership practices from the 225 characteristics studied. All of these traits were evaluated and included in categories based on 20 traits. These traits will reveal the top five specific factors in representing common practices for successful leaders. The research and analysis of Kouzes and Posner (2012), leadership can be learned and anyone can engage in organizational leadership with leadership practices in the Leadership Practices Inventory regardless of the level or rank of the individual. The five leadership practices of Kouzes and Posner (2012) are model the way, inspire a share vision, challenge the process, enable others to act and encourage the heart.

\section{Research Methodology \\ Pre-test}

According to Bahkia et al $(2019,2020)$, Hoque et al $(2017,2018)$; Shkeer \& Awang (2019), pretest, pilot study and Exploratory Factor Analysis (EFA) procedure is required for research that adapted and modified the measuring instrument in order to suit the study at hand. The process is crucial since the original instrument was developed in the population of different culture and different industry from the present study (Muda et al., 2018, 2020). In this study, the measuring instrument of Leadership Practice construct was adapted from the Leadership Practice Inventory (LPI). After the modification process, the instrument was reviewed by two language experts. The researcher followed the guidelines of the back-to-back translation procedure as suggested by Brislin (1980). The researcher modified the instrument accordingly based on the comments and suggestions by the language experts.

The instrument in the Bahasa Malaysia version was reviewed by four experts in the field of leadership and management. The experts assessed the instrument on the word's appropriateness, items clarity, sufficient item to measure the construct, the questionnaire arrangement and reworded to avoid double-barrelled questions. The experts made some valuable comments for some of the item statement. The researcher amended the items accordingly in order to achieve the content validity and face validity for the instrument. Therefore, the new version of instrument in the context of Malaysia produced and suitable for measuring the leadership practice among the lecturer in matriculation college.

\section{Exploratory Factor Analysis}

This study employed the Exploratory Factor Analysis (EFA) procedure to explore and assess the usefulness of items and determine the dimensionality of the construct. The EFA procedure was carried out using data from the pilot study. The pilot study applied the cross-sectional research design. The pilot study data was collected from 100 randomly selected lecturers from Kedah Matriculation College using a self-administered questionnaire.

The EFA technique would produce the best suitable elements for every component (Sekaran, 2009; Ehido et al., 2020). Bartlett's test was applied to test the possibility of factor analysis stability. Whereas the KMO test was used to determine the adequacy of sample size for analysis.

The EFA procedure would compute factor loading for every item, which indicates the usefulness in measuring the construct, as well as determine the dimensionality of items. According to Alias et al (2019), the minimum accepted value for factor loading is 0.60 . Furthermore, the EFA procedure also determines the Total Variance Explained. Mahfouz et al. (2019) stated that Total Variance Explained indicates how much the measuring items and 
their components manage to estimate the construct. Suggested by Muda et al. (2018), the minimum value for Total Variance Explained is 0.60 . This means that the items and their components should be able to measure at least $60 \%$ of the construct. The last part of EFA procedure would be the computation of internal reliability for measuring items through Cronbach Alpha. Based on Rahlin et al (2019); Bahkia et al $(2019,2020)$, the internal reliability indicates how much the selected items are holding to each other in measuring the construct. The minimum value of Cronbach Alpha is 0.7 (Nunally's, 1978; Sekaran \& Bougie, 2010; Awang, 2012, 2014).

The researcher used the retained items with factor loading greater than 0.6 to collect data from the field once the items and their components are determined.

\section{Discussion and Conclusion}

Exploratory Factor Analysis (EFA) is employed to explore and assess the items and their dimensionality in measuring the particular construct (Al-edenat, 2018; Wesam Ali, 2018). The dimensionality of items may change according to the field of study, the socio-economic status and the culture of population. Therefore, the dimensionality of the current study is differed from other studies. Another factor that affects the dimensionality of the study is the gap of time between the current study and previous studies. The results obtained by other studies may not valid due to the differences as mentioned above (Majid et al., 2019; Mohamad et al., 2019).

\section{EFA Procedure}

This study used a 10-point interval scale ranging from 1 (strongly disagree) to 10 (strongly agree) with the given element statement to measure the leadership practice construct with its 30 items in the instrument. According to Awang et al. (2016), 10 points scale is more accurate when compared to 5 points scale in the measurement model because of more extensive choice and more independence. Table 1 show the results of descriptive statistics for each item measuring the leadership practice construct. The mean value for every item ranged from 6.96 to 9.29, while the standard deviation of the value ranged from 0.909 to 2.128 . 
Table 1: The descriptive Statistics for Items Measuring Leadership Practice Construct

\section{Item Statement}

Mean Standard

Deviation

\begin{tabular}{|c|c|c|c|}
\hline \multicolumn{4}{|c|}{ (A) Model the Way } \\
\hline PM1 & I set a personal example of what I expect of others. & 8.34 & 1.375 \\
\hline PM2 & $\begin{array}{l}\text { I spend time and energy making certain that the people } \\
\text { I work with adhere to the principles and standards we } \\
\text { have agreed on. }\end{array}$ & 8.25 & 1.231 \\
\hline PM3 & $\begin{array}{l}\text { I follow through on promises and commitments that I } \\
\text { make. }\end{array}$ & 8.69 & 1.031 \\
\hline PM4 & $\begin{array}{l}\text { I ask for feedback on how my actions affect other } \\
\text { people's performance. }\end{array}$ & 8.49 & 1.174 \\
\hline PM5 & $\begin{array}{l}\text { I build consensus around a common set of values for } \\
\text { running our organization. }\end{array}$ & 8.35 & 1.316 \\
\hline PM6 & I am clear about my philosophy of leadership. & 8.63 & 1.329 \\
\hline \multicolumn{4}{|c|}{ (B) Inspire a Share Vision } \\
\hline VB1 & $\begin{array}{l}\text { I talk about future trends that will influence how our } \\
\text { work gets done. }\end{array}$ & 8.35 & 1.274 \\
\hline VB2 & $\begin{array}{l}\text { I describe a compelling image of what our future could } \\
\text { be like. }\end{array}$ & 8.59 & 1.112 \\
\hline VB3 & $\begin{array}{l}\text { I appeal to others to share an exciting dream of the } \\
\text { future. }\end{array}$ & 8.63 & 1.308 \\
\hline VB4 & $\begin{array}{l}\text { I show others how their long-term interest can be } \\
\text { realized by enlisting in a common vision. }\end{array}$ & 8.05 & 1.492 \\
\hline VB5 & $\begin{array}{l}\text { I paint the "big picture" of what we aspire to } \\
\text { accomplish. }\end{array}$ & 8.11 & 1.466 \\
\hline VB6 & $\begin{array}{l}\text { I speak with genuine conviction about the higher } \\
\text { meaning and purpose of our work. }\end{array}$ & 8.37 & 1.349 \\
\hline \multicolumn{4}{|c|}{ (C) Challenge the Process } \\
\hline PC1 & $\begin{array}{l}\text { I seek out challenging opportunities that test my own } \\
\text { skills and abilities. }\end{array}$ & 8.89 & 1.018 \\
\hline PC2 & $\begin{array}{l}\text { I challenge people to try out new and innovative ways } \\
\text { to do their work. }\end{array}$ & 8.97 & 1.036 \\
\hline PC3 & $\begin{array}{l}\text { I search outside the formal boundaries of my } \\
\text { organization for innovative ways to improve what we } \\
\text { do. }\end{array}$ & 8.71 & 1.222 \\
\hline PC4 & $\begin{array}{l}\text { I ask “What can we learn?” when things don't go as } \\
\text { expected. }\end{array}$ & 8.77 & 1.171 \\
\hline PC5 & $\begin{array}{l}\text { I make certain that we set achievable goals, make } \\
\text { concrete plans, and establish measurable milestone for } \\
\text { the projects and programs that we work on. }\end{array}$ & 8.87 & 1.103 \\
\hline PC6 & $\begin{array}{l}\text { I experiment and take risks, even when there is a } \\
\text { chance of failure. }\end{array}$ & 8.84 & 1.100 \\
\hline \multicolumn{4}{|c|}{ (D) Enable Others to Act } \\
\hline TB1 & $\begin{array}{l}\text { I develop cooperative relationships among the people I } \\
\text { work with. }\end{array}$ & 8.77 & 1.270 \\
\hline
\end{tabular}




\begin{tabular}{llll} 
TB2 & I actively listen to diverse points of view. & 8.56 & 1.459 \\
\hline TB3 & I treat others with dignity and respect. & 8.80 & 1.306 \\
\hline TB4 & I support the decisions that people make on their own. & 8.69 & 1.204 \\
\hline TB5 & $\begin{array}{l}\text { I give people a great deal of freedom and choice in } \\
\text { deciding how to do their work. }\end{array}$ & 9.29 & 0.909 \\
\hline TB6 & $\begin{array}{l}\text { I ensure that people grow in their jobs by learning new } \\
\text { skills and developing themselves. }\end{array}$ & 9.01 & 1.013 \\
\hline (E) Encourage the Heart & & \\
\hline GK1 & I praise people for a job well done. & 7.77 & 1.680 \\
\hline GK2 & $\begin{array}{l}\text { I make it a point to let people know about my } \\
\text { confidence in their abilities. }\end{array}$ & 7.19 \\
\hline GK3 & $\begin{array}{l}\text { I make sure that people are creatively rewarded for } \\
\text { their contributions to the success of our projects. }\end{array}$ & 6.96 & 2.128 \\
\hline GK4 & $\begin{array}{l}\text { I publicly recognize people who exemplify commitment } \\
\text { to shared values. }\end{array}$ & 7.59 & 1.781 \\
\hline GK5 & I find ways to celebrate accomplishments. & 8.35 & 1.502 \\
\hline GK6 & $\begin{array}{l}\text { I give the members of the team lots of appreciation and } \\
\text { support for their contributions. }\end{array}$ & 8.43 & 1.716 \\
\hline
\end{tabular}

\section{Bartlett's Test and KMO Value}

The Exploratory Factor Analysis (EFA) using the extraction method of Principal Component Analysis with Varimax (Variation Maximization) Rotation was performed on these 30 items measuring the Leadership Practice construct. The results in Table 2 indicate that the Bartletts' Test of Sphericity is significant ( $\mathrm{P}$-Value $<0.05)$. Furthermore, the measure of sampling adequacy by Kaiser-Meyer-Olkin (KMO $=0.834$ ) is excellent since it exceeded the required value of 0.6 (Awang, 2012; Noor et al., 2015; Asnawi et al., 2019). These two results (Bartlett's Test is significant and $\mathrm{KMO}>0.6$ ) indicate that the data is adequate to proceed further with the data reduction procedure in EFA (Hoque et al., 2017, 2018; Yahaya et al., 2018).

Table 2: The KMO and Bartlett's Test Score

\begin{tabular}{lll}
\hline KMO and Bartlett's Test & & \\
\hline Kaiser-Meyer_Olkin Test for Sample Adequacy & .834 \\
\hline Bartlett's Test of Sphericity & $\begin{array}{l}\text { Approx. Chi- } \\
\text { Square }\end{array}$ & 3222.240 \\
\cline { 2 - 3 } & Df & 435 \\
\cline { 2 - 3 } & Sig. & .000 \\
\hline
\end{tabular}

The scree plot in Figure 1 clearly indicates five components that emerged from EFA procedure for this latent construct. In other words, the EFA procedure has grouped 30 items into five components (Awang, 2012, 2014 and Awang et al., 2018). 


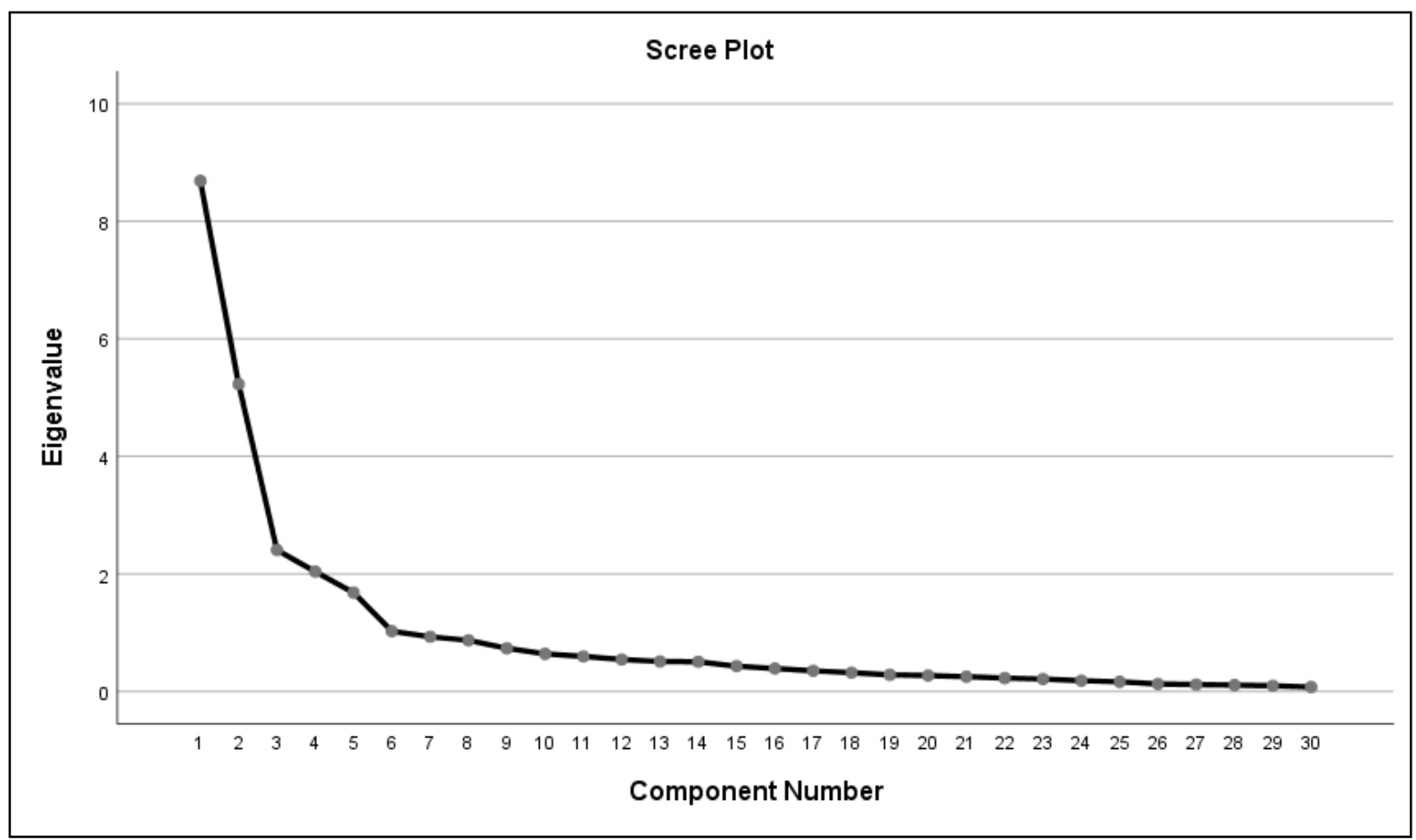

Figure 1: The Scree Plot shows clearly five components emerged from the EFA procedure

\section{The Total Variance Explained for Leadership Practice Construct}

The results in Table 3 show there are five components emerged from the EFA procedure based on the computed Eigenvalue greater than 1.0. The eigenvalues ranged between 3.509 and 4.350 . The total variance explained for component 1 is $14.499 \%$, component 2 is $14.101 \%$, component 3 is $13.657 \%$, component 4 is $12.852 \%$ and component 5 is $11.695 \%$. To measure this construct, the total variance explained is $66.804 \%$. The total variance explained is acceptable since it exceeded the minimum requirement of $60 \%$ (Awang et al., 2015; Alias et al., 2019).

Table 3: The Total Variance Explained for the construct

\begin{tabular}{|c|c|c|c|c|c|c|}
\hline \multirow{2}{*}{$\begin{array}{c}\text { Componen } \\
\mathrm{t}\end{array}$} & \multicolumn{3}{|c|}{ Initial Eigenvalues } & \multicolumn{3}{c|}{ Rotation Sums of Squared Loadings } \\
\cline { 2 - 7 } & Total & $\begin{array}{c}\text { \% of } \\
\text { Variance }\end{array}$ & $\begin{array}{c}\text { Cumulative } \\
\%\end{array}$ & Total & \% of Variance & Cumulative \% \\
\hline 1 & 8.687 & 28.957 & 28.957 & 4.350 & 14.499 & 14.499 \\
\hline 2 & 5.228 & 17.426 & 46.383 & 4.230 & 14.101 & 28.600 \\
\hline 3 & 2.407 & 8.023 & 54.407 & 4.097 & 13.657 & 42.257 \\
\hline 4 & 2.038 & 6.793 & 61.200 & 3.856 & 12.852 & 55.109 \\
\hline 5 & 1.681 & 5.604 & 66.804 & 3.509 & 11.695 & $\mathbf{6 6 . 8 0 4}$ \\
\hline
\end{tabular}

Extraction Method: Principal Component Analysis

The following table, Table 4 present five components emerged and their respective items resulted from the EFA procedure. The factor loading for every item should be greater than 0.6 in order to be retained (Muda et al., 2018; Yahaya et al., 2018). The item needs to be deleted if it failed to achieve the minimum requirement for factor loading of 0.6 (Awang, 2015; Afthanorhan et al., 2017 and Awang et al., 2018). Table 4 presented the items and their respective factor loading. Item VB1, TB5 dan GK5 have the factor loading less than 0.6, 
consequently these 3 items have to delete from the instrument. As a result, the instrument that measuring Leadership Practise using LPI only have 27 items after the EFA procedure.

Table 4: Item and Factor Loading

\begin{tabular}{|c|c|c|c|c|c|}
\hline \multicolumn{6}{|c|}{ Rotated Component Matrix } \\
\hline & \multicolumn{5}{|c|}{ Component } \\
\hline & 1 & 2 & 3 & 4 & 5 \\
\hline PM1 & .756 & & & & \\
\hline PM2 & .796 & & & & \\
\hline PM3 & .838 & & & & \\
\hline PM4 & .704 & & & & \\
\hline PM5 & .757 & & & & \\
\hline PM6 & .655 & & & & \\
\hline \multicolumn{6}{|l|}{ VB1 } \\
\hline VB2 & & & .683 & & \\
\hline VB3 & & & .768 & & \\
\hline VB4 & & & .826 & & \\
\hline VB5 & & & .826 & & \\
\hline VB6 & & & .655 & & \\
\hline PC1 & & & & .702 & \\
\hline PC2 & & & & .679 & \\
\hline PC3 & & & & .765 & \\
\hline PC4 & & & & .805 & \\
\hline PC5 & & & & .731 & \\
\hline PC6 & & & & .750 & \\
\hline TB1 & & & & & .717 \\
\hline TB2 & & & & & .818 \\
\hline TB3 & & & & & .825 \\
\hline TB4 & & & & & .654 \\
\hline \multicolumn{6}{|l|}{ TB5 } \\
\hline TB6 & & & & & .645 \\
\hline GK1 & & .845 & & & \\
\hline GK2 & & .867 & & & \\
\hline GK3 & & .849 & & & \\
\hline GK4 & & .684 & & & \\
\hline \multicolumn{6}{|l|}{ GK5 } \\
\hline GK6 & & .688 & & & \\
\hline
\end{tabular}

Extraction Method: Principal Component Analysis.

Rotation Method: Varimax with Kaiser Normalization.

a. Rotation converged in 7 iterations.

The Internal Reliability for the Instrument Measuring Leadership Practice Construct Finally, the study needs to compute the value of Cronbach's Alpha which reflect the Internal Reliability for the retained items in measuring their latent construct. The internal reliability or internal consistency indicates how strong the respective items are holding together in measuring the respective construct. The value of Cronbach's Alpha should be greater than 0.7 
for the items to achieve the Internal Reliability (Awang, 2012, 2015). Table 5 presented the Cronbach Alpha for Leadership Practice construct.

Table 5: The Internal Reliability for Leadership Practice Construct

\begin{tabular}{|c|l|c|c|}
\hline \multicolumn{3}{|c|}{ Reliability Statistics } \\
\hline Component & \multicolumn{1}{|c|}{ Name } & No. of Items & Cronbach's Alpha \\
\hline 1 & Model the Way & 6 & 0.899 \\
\hline 2 & $\begin{array}{l}\text { Inspire a Share } \\
\text { Vision }\end{array}$ & 5 & 0.898 \\
\hline 3 & $\begin{array}{l}\text { Challenge the } \\
\text { Process }\end{array}$ & 5 & 0.763 \\
\hline 4 & Enable Others to Act & 6 & 0.879 \\
\hline 5 & Encourage the Heart & 5 & 0.848 \\
\hline & Total & $\mathbf{2 7}$ & $\mathbf{0 . 8 9 7}$ \\
\hline
\end{tabular}

The Cronbach value in Table 5 indicate the items in every component measuring the Leadership Practice construct have good internal reliability (Cronbach $>0.7$ ), and more importantly the internal reliability for the whole construct is 0.897 . This value has exceeded the minimum threshold value of 0.70 for Cronbach's Alpha (Alias et al., 2019; Ehido et al., 2020; Muda et al., 2018, 2020).

This research adds a remarkable contribution to the measurement of the Leadership Practice construct in Leadership Practice Inventory (LPI), mainly in the Malaysian Matriculation College context. The EFA procedure demonstrated five components of extraction for Leadership Practice construct, which can be measured using 27 items established in this research, with high Cronbach Alpha value, meet Bartlett's Test achievements (significant), KMO (>.60), and factor loading exceeds the minimum threshold of 0.6. These results reveals that the items are applicable in this study (Asnawi et al., 2019; Mohamad et al., 2019; Majid et al., 2019). The EFA procedure confirmed the validated instrument is consistent and stable across samples. The instrument for measuring Leadership Practice construct can be used in future studies especially in Malaysia context.

\section{Limitation}

This study focussed on the lecturers of Matriculation College in Malaysia which might not be generalizable for other industries in terms of the industrial setting, organisational culture and the nature of the work.

\section{Correspondent Author}

Kang Kooi Wei

Email: kangkooiwei@gmail.com

\section{References}

Afthanorhan, A., Awang, Z., \& Fazella, S. (2017). Developing the patients' loyalty model for medical tourism industry: the case of Malaysia. International Journal of Society Systems Science, 9(2), 139-164.

Aimran, A. N., Ahmad, S., Afthanorhan, A., \& Awang, Z. (2017). The development of the comparative bias index. Paper presented at the AIP Conference Proceedings, 1870. https://doi.org/10.1063/1.4995935 
Al-edenat, M. (2018). Reinforcing innovation through transformational leadership: the mediating role of job satisfaction. Journal of Organizational Change Management, 31(4), 810-838. https://doi.org/10.1108/JOCM-05-2017-0181

Alias, N., Awang, Z., \& Muda, H. (2019). Policy Implementation Performance of Primary School Leaders in Malaysia: An Exploratory Factor Analysis. IIUM Journal of Educational Studies, 7(2), 22-39.

Asnawi, A., Awang, Z., Afthanorhan, A., Mohamad, M., \& Karim, F. (2019). The influence of hospital image and service quality on patients' satisfaction and loyalty. Management Science Letters, 9(6), 911-920. https://doi.org/10.5267/j.msl.2019.2.011

Awang, Z. (2012). Research methodology and data analysis. Penerbit Universiti Teknologi MARA Press. Malaysia.

Awang, Z. (2014). A handbook on SEM for academicians and practitioners: the step by step practical guides for the beginners. Bandar Baru Bangi, MPWS Rich Resources.

Awang, Z. (2015). SEM Made Simple: A Gentle Approach to Learning Structural Equation Modelling. Bandar Baru Bangi, MPWS Rich Resources.

Awang, Z., Lim, S. H., \& Zainudin, N. F. S. (2018). Pendekatan Mudah SEM-Structural Equation Modelling. Bandar Baru Bangi, MPWS Rich Resources.

Awang, Z., Afthanorhan, A., Mohamad, M., \& Asri, M. A. M. (2015). An evaluation of measurement model for medical tourism research: the confirmatory factor analysis approach. International Journal of Tourism Policy, 6(1), 29-45.

Bahkia, A. S., Awang, Z., Afthanorhan, A., Ghazali, P. L., Foziah, H. (2019). Exploratory Factor Analysis on occupational stress in context of Malaysian sewerage operations. AIP Conference Proceedings. https://doi.org/10.1063/1.5121111

Bahkia, A. S., Awang, Z., Rahlin, N. A., Zulkifli, A. R. (2020). The Importance of Supportive Leadership in the Sewerage Operation Industry: A case of Indahwater Konsortium Private IWK). Humanities \& Social Science Reviews, 8(3), 2020, 149-162. https://doi.org/10.18510/hssr.2020.8317

Ehido, A., Awang, Z., Halim, B. A., \& Ibeabuchi, C. (2020). Establishing Valid and Reliable Measures for Organizational Commitment and Job Performance: An Exploratory Factor Analysis. International Journal of Social Sciences Perspectives 7 (2), 58-70.

Hoque, A. S. M. M., Awang, Z., Jusoff, K., Salleh, F., \& Muda, H. (2017). Social Business Efficiency: Instrument Development and Validation Procedure using Structural Equation Modelling. International Business Management, 11(1), 222-231.

Hoque, A. S. M., Siddiqui, B. A., Awang, Z. B., \& Baharu, S. M. A. (2018). Exploratory factor analysis of entrepreneurial orientation in the context of Bangladesh small and medium enterprises (SMES). European Journal of Management and Marketing Studies, 3(2), 81-94.

Mahfouz, S., A., Awang, Z., \& Muda, H. (2019). The Impact of Transformational Leadership on Employee Commitment in the Construction Industry. International Journal of Innovation, Creativity and Change, 7(10).

Majid, N. A., Zainol, F. A., Daud, W. N. W., \& Afthanorhan, A. (2019). Cooperative Entrepreneurship in Malaysian Secondary Schools: A Review of Current Practices. The Journal of Social Sciences Research, 5(3), 812-818. https://doi.org/10.32861/jssr.53.812.818

Mohamad, M., Afthanorhan, A., Awang, Z., \& Mohammad, M. (2019). Comparison Between CB-SEM and PLS-SEM: Testing and Confirming the MaqasidSyariah Quality of Life 
Measurement Model. The Journal of Social Sciences Research, 5(3), 608-614. https://doi.org/10.32861/jssr.53.608.614

Muda, H., Baba, Z. S., Awang, Z., Badrul, N. S., Loganathan, N., \& Ali, M. H. (2020). Expert review and pretesting of behavioral supervision in higher education. Journal of Applied Research in Higher Education.

Muda, H., Loganathan, N., Awang, Z., Jusoh, H., \& Baba, Z. S. (2018). Application of Theory, Methodology and Analysis in Conducting Research. A Practical Guide to Quantitative Research and Thesis Writing, UniSZA Publisher, ISBN: 978-967-2231-11-0

Nunnally, J. C. (1978). An overview of psychological measurement. In Clinical diagnosis of mental disorders (pp. 97-146). Springer, Boston, MA.Norman, A. S. (2010). Importance of financial education in making informed decision on spending. Journal of economics and International Finance, 2(10), 199-207. https://doi.org/10.1007/978-1-4684-24904_4

Rahlin, N. A., Awang, Z., Afthanorhan, A., \& Aimran, N. (2019). The Art of Covariance Based Confirmatory Factor Analysis: Evidence from SME'S. International Journal of Innovation, Creativity and Change, 5(2).

Sekaran, U. (2009). Research methods for business 4th edition. Hoboken: NJ: John Wiley \& Sons.

Sekaran, U., \& Bougie, R. (2010) Research Methods for Business: A Skill Building Approach, Wiley.

Shkeer, A. S., \& Awang, Z. (2019). Exploring Items for Measuring Marketing Information System Construct: An Exploratory Factor analysis. International Review of Management and Marketing, 9(6), 87-97. https://doi.org/10.32479/irmm.8622

Ali, W. S. N., Noori, S. (2018). The pillars of Blue Ocean leadership and their impact on team empowerment strategies.

Yahaya, T., Idris, K., Suandi, T., \& Ismail, I. (2018). Adapting instruments and modifying statements: The confirmation method for the inventory and model for information sharing behavior using social media. Management Science Letters, 8(5), 271-282. 